\title{
CORRIGENDUM
}

\section{Gene transfer in human skin with different pseudotyped HIV-based vectors}

A Hachiya, P Sriwiriyanont, A Patel, N Saito, A Ohuchi, T Kitahara, Y Takema, R Tsuboi, RE Boissy, MO Visscher, JM Wilson and GP Kobinger

Gene Therapy (2007) 14, 709. doi:10.1038/sj.gt.3302954

Correction to: Gene Therapy (2007) 14, 648-647. doi: 10.1038/ sj.gt.3302915

Since the above publication, the authors have noticed that Dr Wilson's name was published incorrectly.
The correct name is shown above. The authors would like to apologise for this error. 